\title{
Data report: strength characteristics of sediments from IODP Expedition 308, Sites U1322 and U1324'
}

\author{
Brandon Dugan² and John T. Germaine ${ }^{3}$
}

\section{Chapter contents}

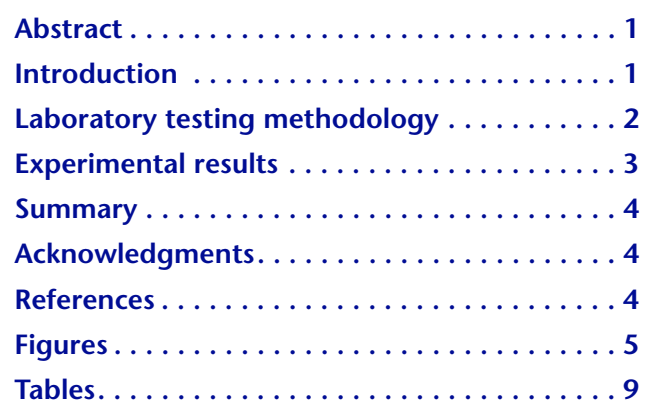

'Dugan, B., and Germaine, J.T., 2009. Data report: strength characteristics of sediments from IODP Expedition 308, Sites U1322 and U1324. In Flemings, P.B., Behrmann, J.H., John, C.M., and the Expedition 308 Scientists, Proc. IODP, 308: College Station, TX (Integrated Ocean Drilling Program Management International, Inc.). doi:10.2204/iodp.proc.308.210.2009

${ }^{2}$ Department of Earth Science, Rice University, Houston TX 77005, USA.

dugan@rice.edu

${ }^{3}$ Department of Civil and Environmental Engineering, Massachusetts Institute of Technology, Cambridge MA 02139, USA.

\begin{abstract}
Triaxial strength experiments completed on specimens from Integrated Ocean Drilling Program Expedition 308 Sites U1322 and U1324 document internal friction angles from $17^{\circ}$ to $29^{\circ}$ and normalized undrained shear strength from 0.21 to 0.36 at maximum shear. Just prior to undrained shearing, lateral stress ratios for these triaxial specimens range from 0.50 to 0.73 . In general, internal friction angle and normalized undrained shear strength decrease with increasing vertical consolidation stress. Lateral stress ratio does not vary systematically with vertical consolidation stress. All 18 specimens in this study were collected with the advanced piston corer (APC). Specimens from Site U1322 were from 27.3-72.9 meters below seafloor (mbsf), and those from Site U1324 were from 89.1-304 mbsf. For each specimen we completed a $K_{\mathrm{o}}$-consolidated undrained triaxial test to provide data on the stress-strain behavior, undrained shear strength, internal friction angle, and secant modulus. Undrained shearing for each specimen was conducted at a vertical consolidation stress exceeding the hydrostatic vertical effective stress for that specimen.
\end{abstract}

\section{Introduction}

Integrated Ocean Drilling Program (IODP) Expedition 308 was dedicated to understanding fluid flow, in situ pressure, and slope stability in rapidly deposited sediments of the northern Gulf of Mexico. The Ursa region was one of the focus areas for Expedition 308 because of high-quality multichannel seismic data illuminating depositional architecture (Sawyer et al., 2007), previous industry drilling that documented overpressure in shallow sand and mud (Ostermeier et al., 2001; Pelletier et al., 1999), and a series of stacked mass-transport complexes (MTCs) (see the "Expedition 308 summary" chapter). The Ursa region is $210 \mathrm{~km}$ southeast of New Orleans, Louisiana (USA) in 1000-1300 m water depth (Fig. F1). Sites U1322 and U1324 are separated by $12 \mathrm{~km}$ along a westsouthwest-east-northeast transect (Fig. F1).

Three-dimensional seismic data over the Ursa region show a basin floor fan (Blue Unit) overlain by mud-dominated levee deposits (see the "Expedition 308 summary" chapter). These levee deposits are thick near Site U1324 and thin toward Site U1322. The stacked MTCs are confined within these levee deposits. Drilling was proposed in this region to understand how flow within the 
Blue Unit affects pressure and stability in the bounding mud. The overpressure profiles at Sites U1324 and U1322 have been characterized through direct measurements (Flemings et al., 2008) and laboratory experiments (Long et al.). We present constraints on the strength of sediments from these sites based on triaxial experiments.

Whole-round samples were used in detailed triaxial experiments to evaluate the stress-strain behavior, undrained strength, friction angle, and modulus. These results complement grain size analyses (Sawyer et al.), consolidation and hydraulic conductivity analyses (Long et al.) of sediment, and permeability analyses (Schneider et al.) of sediments from this region. Together these studies provide a full suite of geotechnical parameters which will help us understand coupling between flow, deformation, and stability and can be used for inputs into basin models.

\section{Laboratory testing methodology}

All laboratory tests (Table T1) were conducted in accordance with the American Society for Testing and Materials (ASTM) standards. For tests where ASTM standards do not exist, the procedures followed the established Massachusetts Institute of Technology (MIT) geotechnical laboratory protocols.

\section{Radiography}

Radiography allows the selection of the best quality material for advanced geotechnical testing. All whole-round samples were X-rayed following a procedure similar to ASTM standard D4452 (ASTM International, 2003). X-ray images were used to assess sample quality, presence of inclusions, general soil type, and variation in soil layering. Radiographs are available in Nelson et al.

\section{Specimen index properties}

Water content is measured by taking the difference in the weight of a soil before and after oven drying and then dividing this difference by the oven-dried weight. For each experiment we provide the water content of the test specimen $\left(w_{n}\right)$ (Tables T2, T3). We also provide the initial void ratio $\left(e_{i}\right)$ of each specimen (Tables T2, T3). Void ratio is defined as the volume of voids divided by the volume of solids. From the void ratio and water content we calculate the initial saturation $\left(S_{i}=w_{\mathrm{n}} \mathrm{G}_{\mathrm{s}} / e_{i}\right)$ for each specimen (Tables T2, T3). We assume a constant specific gravity of the solid grains $\left(G_{s}=2.78\right)$ for these clay-rich samples. All variables are defined in Table T4.

\section{Undrained strength testing}

Consolidation and strength properties were measured from the results of $K_{\mathrm{o}}$-consolidated undrained $\left(\mathrm{CK}_{\mathrm{o}} \mathrm{U}\right)$ triaxial tests on specimens from Sites U1322 and U1324. The MIT geotechnical laboratory has developed a standard method for performing $\mathrm{CK}_{\mathrm{o}} \mathrm{U}$ tests. In addition, ASTM standard D4767 (ASTM International, 2004) was used as a reference for the triaxial testing. Undrained strength testing can be divided into four stages. The first stage of the test involves sample preparation by trimming the specimen in a trimming jig using a wire saw. After the sample is trimmed $(\sim 1.75 \mathrm{~cm}$ radius; $\sim 8 \mathrm{~cm}$ height), it is placed on the triaxial base with a nylon filter fabric and a porous stone placed on each end. Side drains were not used. Two thin, impermeable membranes are rolled over each specimen and sealed with three O-rings each at the top cap and bottom base of the triaxial chamber. The triaxial cell is then filled with silicon oil and tightly sealed. Distilled water was used as the fluid in the drainage system, which is connected to the top and base of the specimen.

Backpressure saturation is the second stage of the test. This phase ensures full saturation of the specimen. To do this, a modest pressure is applied to dissolve any air bubbles in the specimen. Next, a small, isotropic effective stress is applied to the specimen such that there is minimal to no axial strain. This effective stress is applied to seat the specimen in the triaxial cell. For the specimens from the Ursa region, the applied effective stress ranged from 16 to $76 \mathrm{kPa}$ (Table T2). This isotropic effective stress is maintained while the axial stress and cell pressure are increased incrementally by the same value. To test for specimen saturation, the drainage lines are closed and the axial stress and cell pressure are increased incrementally and the $B$ value (ASTM International, 2004 ) is measured. A $B$ value of $0.98-1.00$ is desired; however, it was not achieved in all experiments (Table T2). After the $B$ value is measured, the drainage lines are opened for the consolidation phase of the test.

The third test stage is $K_{\mathrm{o}}$ consolidation. During $K_{\mathrm{o}}$ consolidation the specimen is consolidated one-dimensionally in the axial direction (i.e., no radial strain) following the SHANSHEP testing technique (Ladd, 1986). $K_{\mathrm{o}}$ consolidation allows vertical strain on the specimen but maintains the radius of the specimen. This simulates burial of the sediment in a confined basin where sediments deform vertically but are confined laterally and do not strain in the lateral direction. $K_{\mathrm{o}}$ is the ratio of the radial effective stress to the vertical effective stress required to main- 
tain no radial strain $\left(K_{\mathrm{o}}=\sigma_{\mathrm{r}}{ }^{\prime} / \sigma_{\mathrm{a}}{ }^{\prime}\right)$. We define $K_{\mathrm{o}}$ at the maximum vertical consolidation stress $\left(\sigma_{\mathrm{vc}}{ }^{\prime}\right)$ as the consolidation lateral stress ratio $\left(K_{c}\right)$ (Table T2). $K_{\circ}$ consolidation rates are provided in Table $\mathbf{T} 2$. After reaching the desired consolidation stress, total vertical stress, cell pressure, and pore pressure were held constant for a set time $\left(t_{s}\right)$ to allow excess pore pressure to dissipate and to allow some secondary compression (Table T2). For all specimens the maximum vertical consolidation stress exceeds the in situ effective vertical stress to ensure the specimen is on the primary consolidation path.

The final stage of the test is undrained shearing. Prior to starting the shear, a leak check is performed by closing the drainage valves for $30 \mathrm{~min}$. During this time, the backpressure should remain constant. After the leak check, the specimen is sheared with the drainage lines closed. Shearing with the drainage lines closed prevents any fluid drainage during shear, maintains a constant volume of the specimen, and allows us to define the undrained strength parameters for each specimen. The shear rates are provided in Table T3. Positive shear strain data indicate a compression test, whereas negative shear strain data indicate an extension test.

\section{Experimental results}

All specimen locations, depths, and corresponding triaxial experiments are provided in Table T1. Table T2 summarizes the consolidation phase of each experiment, and Table $\mathrm{T} 3$ provides information on the shear phase of each experiment. Complete experimental data are provided in "Supplementary material."

\section{Consolidation results}

We describe the initial conditions and consolidation parameters for each specimen (Table T2). The specimen data define the initial conditions of the specimen including $w_{\mathrm{n}}$, total density $\left(\rho_{\mathrm{t}}\right), e_{\mathrm{i}}$, and $S_{\mathrm{i}}$. Specimen water contents ranged from $28 \%$ to $50 \%$, and initial void ratios ranged from 0.84 to 1.4 . $\mathrm{G}_{\mathrm{s}}$ was assumed to be 2.78. Initial consolidation conditions define the specimen and cell conditions prior to the start of $K_{\mathrm{o}}$ consolidation. $\sigma_{i}^{\prime}$ is the initial vertical effective stress applied to the specimen and $\varepsilon_{\mathrm{a}}$ is the axial strain after this initial stress is applied. $u_{\mathrm{b}}$ is the backpressure applied to the specimen. $\varepsilon_{\mathrm{vol}}$ is the total volume strain to the specimen during backpressure saturation. $B$ is the pore pressure parameter $(B=\Delta u)$ $\left.\Delta \sigma_{\mathrm{r}}\right)$.

The consolidation results portion of the table describes the parameters of the $K_{\mathrm{o}}$ consolidation. The strain rate $\left(\varepsilon_{\mathrm{a}} / \mathrm{h}\right)$ defines the constant rate of axial strain maintained during consolidation. Strain rates for each experiment were constant but varied from $0.05 \% / \mathrm{h}$ to $0.23 \% / \mathrm{h}$ between experiments (Table T2). The specimen conditions at maximum stress define the conditions at the end of primary $K_{\mathrm{o}}$ consolidation. These include $\varepsilon_{a}, \varepsilon_{\mathrm{vol}}$, maximum effective vertical stress $\left(\sigma_{\mathrm{vm}}{ }^{\prime}\right)$, and lateral stress ratio $\left(K_{\mathrm{c}}\right)$ at $\sigma_{\mathrm{vm}}{ }^{\prime}$. The time allowed for secondary compression after reaching $\sigma_{\mathrm{vm}}{ }^{\prime}$ is $t_{\mathrm{s}}$. The final parameters define the conditions at the end of secondary compression including $\sigma_{\mathrm{vc}}{ }^{\prime}$ and overconsolidation ratio (OCR). All experiments were controlled to have an OCR $=1$ such that $\sigma_{\mathrm{vc}}{ }^{\prime}$ was the greatest effective stress to which the specimen was exposed. Prior to initial shearing, the consolidation stress ratio $\left(K_{c}\right)$ for the specimens ranged from 0.50 to 0.73 (Fig. F2).

Standard results from the $K_{\mathrm{o}}$-consolidation phase include the stress-strain behavior, total work done to the specimen, and the lateral stress ratio (Fig. F3). From the stress-strain data, basin model inputs can be constrained and compression behavior can be defined as is done for constant-rate-of-strain consolidation experiments (e.g., Long et al.). The total work data can be used to infer preconsolidation stress for each specimen (Long et al.; Becker et al., 1987). Work is calculated as

$$
\text { work }=\frac{\sigma_{\mathrm{i}}-\sigma_{\mathrm{i}-1}}{2} \ln \left(\frac{1-\varepsilon_{\mathrm{i}-1}}{1-\varepsilon_{\mathrm{i}}}\right) .
$$

Example $K_{\mathrm{o}}$-consolidation phase data are provided in Table T5. Complete $K_{\mathrm{o}}$-consolidation phase data are provided as plots and tables in the CONSOL folder in "Supplementary material."

\section{Strength results}

The shear phase conditions and results are provided in Table T3. The specimen data are identical to those in the consolidation phase (Table T2). The shear phase conditions provided in Table T3 define the strain rate for shearing $\left(\varepsilon_{\mathrm{a}} / \mathrm{h}\right)$ and the stress conditions $\left(K_{c}, \sigma_{v c}{ }^{\prime}\right.$, and OCR) prior to shearing. The next section of the table provides the strength results at maximum shear and obliquity (Table T3). Obliquity refers to the ratio of the normalized shear stress $(q)$ to the normalized mean effective stress $\left(p^{\prime}\right)$. The normalized undrained strength ranges from 0.21 to 0.36 , whereas the friction angle ranges from $17^{\circ}$ to $29^{\circ}$ at maximum shear (Fig. F2; Table T3). Both properties show a relation to the vertical consolidation stress prior to shearing.

Example data from the shear phase are shown in Figure F4 and Table T6. The summary plots include normalized shear stress $\left(q / \sigma_{v c}{ }^{\prime}\right)$ versus $\varepsilon_{a}$, internal friction 
angle $(\phi)$ versus $\varepsilon_{a}$, normalized excess pore pressure $\left(\Delta u_{\mathrm{e}} / \sigma_{\mathrm{vc}}{ }^{\prime}\right)$ and normalized shear-induced pore pressure $\left(\Delta u_{s} / \sigma_{v c}{ }^{\prime}\right)$ versus $\varepsilon_{a}$, and normalized stress path $\left(q / \sigma_{\mathrm{vc}}{ }^{\prime}\right.$ versus $\left.p^{\prime} / \sigma_{\mathrm{vc}}{ }^{\prime}\right)$ for each test. The following equations define $p^{\prime}, q, \phi$, secant modulus $(E)$, and pore pressure parameter $(A)$, which are key parameters in the shear-phase results. All variables are defined in Table T4.

$$
\begin{gathered}
p^{\prime}=\frac{\sigma_{\mathrm{a}}{ }^{\prime}+\sigma_{\mathrm{r}}{ }^{\prime}}{2} \\
q=\frac{\sigma_{\mathrm{a}}-\sigma_{\mathrm{r}}}{2} \\
\phi=\sin ^{-1}\left(\frac{q}{p^{\prime}}\right) \\
E=\frac{2 \Delta q}{\varepsilon} \\
A=\frac{u_{\mathrm{e}}-\Delta \sigma_{\mathrm{r}}}{\Delta \sigma_{\mathrm{a}}-\Delta \sigma_{\mathrm{r}}}
\end{gathered}
$$

Complete data from the undrained shearing portions of the triaxial tests are in the SHEAR folder in "Supplementary material."

\section{Summary}

Triaxial strength experiments on 18 specimens from Sites U1322 and U1324 show that internal friction angle and normalized undrained shear strength generally decrease with increasing vertical consolidation stress. Internal friction angle ranges from $17^{\circ}$ to $29^{\circ}$ and normalized undrained shear strength ranges from 0.36 to 0.21 at maximum shear for vertical consolidation stresses from 230 to $1840 \mathrm{kPa}$. Lateral stress ratios do not exhibit any relation with vertical consolidation stress and range from 0.50 to 0.73 prior to undrained shearing. In conjunction with other physical properties analyses, these strength data help define a complete geotechnical characterization of sediments from the Ursa region.

\section{Acknowledgments}

We thank the participants and technical staff of Expedition 308 for their efforts and assistance in collecting samples for this study. Samples and/or data were provided by the Integrated Ocean Drilling Program (IODP). Funding for this research was provided by the Consortium for Ocean Leadership.

\section{References}

ASTM International, 2003. Standard test method for consolidated undrained triaxial compression test for cohesive soils (Standard D4767-02). In Annual Book of ASTM Standards (Vol. 04.08): Soil and Rock (I): West Conshohocken, PA (Am. Soc. Testing and Mater.), 911-934.

ASTM International, 2004. Standard test method for consolidated undrained triaxial compression test for cohesive soils (Standard D4767-04). In Annual Book of ASTM Standards (Vol. 04.08): Soil and Rock (I): West Conshohocken, PA (Am. Soc. Testing and Mater.).

Becker, D.E., Crooks, J.H.A., Been, K., and Jeffries, M.G., 1987. Work as a criterion for determining in situ and yield stresses in clays. Can. Geotech. J., 24(4):549-564. doi:10.1139/t87-070

Flemings, P.B., Long, H., Dugan, B., Germaine, J., John, C.M., Behrmann, J.H., Sawyer, D., and IODP Expedition 308 Scientists, 2008. Pore pressure penetrometers document high overpressure near the seafloor where multiple submarine landslides have occurred on the continental slope, offshore Louisiana, Gulf of Mexico. Earth Planet. Sci. Lett., 269(3-4):309-325. doi:10.1016/ j.epsl.2007.12.005

Ladd, C.C., 1986. Stability evaluation during staged construction. J. Geotech. Eng., 117(4):540-615.

Ostermeier, R.M., Pelletier, J.H., Winker, C.D., and Nicholson, J.W., 2001. Trends in shallow sediment pore pressure-deepwater Gulf of Mexico. Proc.-SPE/IADC Drill. Conf., 1-11.

Pelletier, J.H., Ostermeier, R.M., Winker, C.D., Nicholson, J.W., and Rambow, F.H., 1999. Shallow water flow sands in the deepwater Gulf of Mexico: some recent Shell experience [International Forum on Shallow Water Flows Conference, League City, TX, October 1999].

Sawyer, D.E., Flemings, P.B., Shipp, R.C., and Winker, C.D., 2007. Seismic geomorphology, lithology, and evolution of the late Pleistocene Mars-Ursa turbidite region, Mississippi Canyon area, northern Gulf of Mexico. AAPG Bull., 91(2):215-234. doi:10.1306/08290605190

Initial receipt: 6 May 2007

Acceptance: 23 July 2008

Web publication: 27 March 2009

MS 308-210 
Figure F1. A. Regional basemap showing the location of the Ursa region, northern Gulf of Mexico. B. Sites U1322 and U1324 in Ursa region of the Mississippi Canyon.
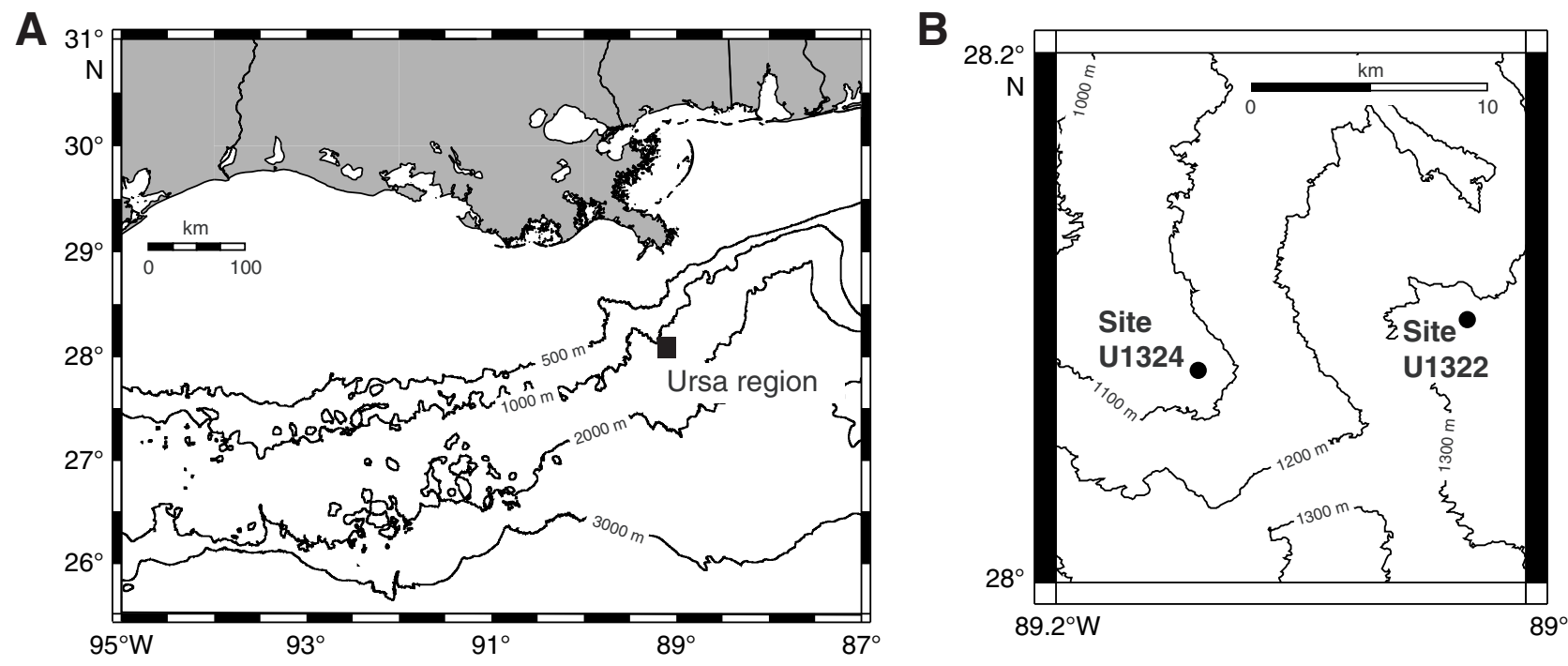
Figure F2. Summary of internal friction angle, normalized shear stress, and lateral stress ratio as a function of maximum vertical consolidation stress. Data are from Tables T2 and T3.
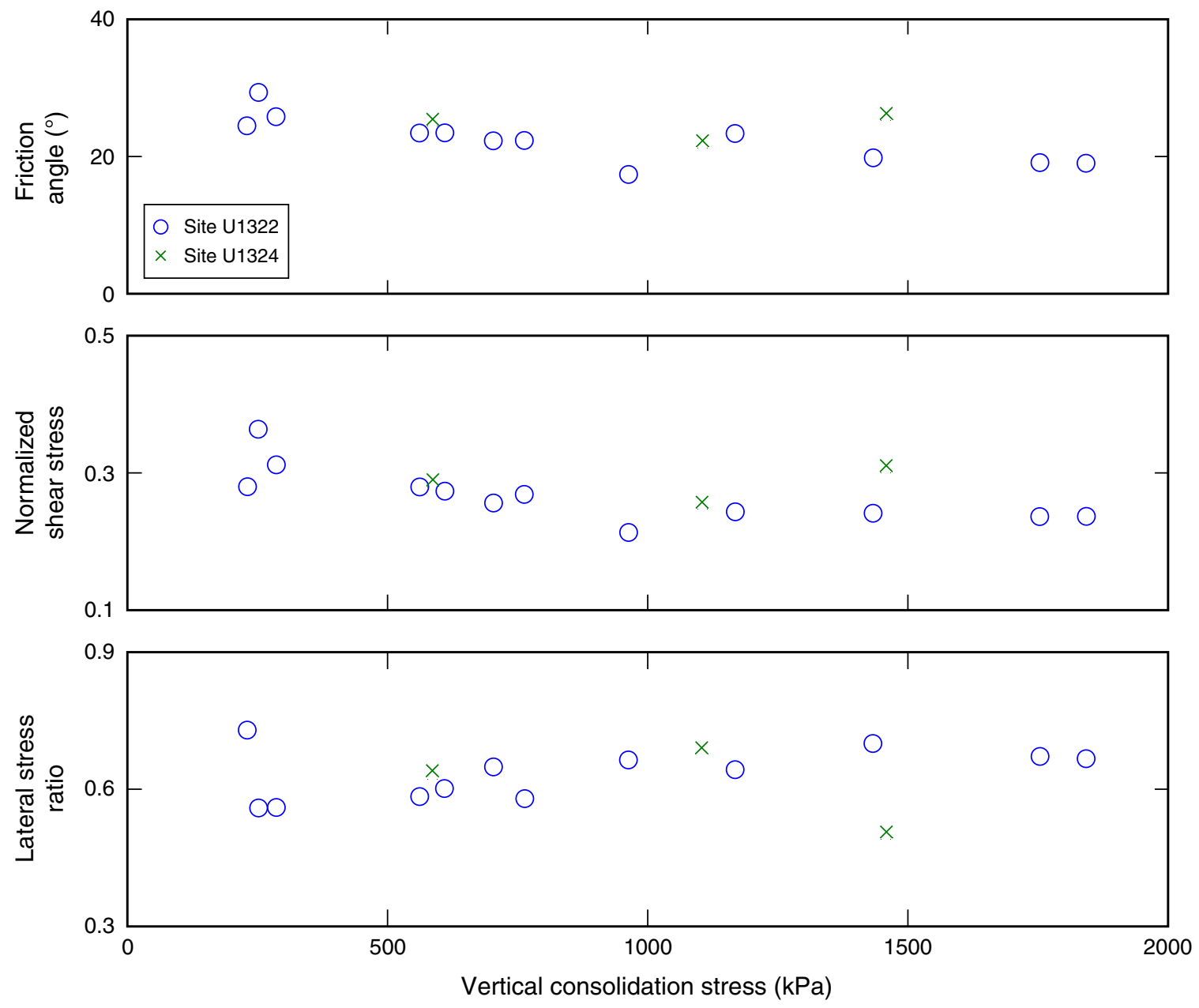
Figure F3. Example data from the consolidation phase of triaxial experiment TX729. Axial strain and void ratio vs. vertical consolidation are plotted on a logarithmic scale that can be used to define stress-strain behavior. Total work and lateral stress ratio $\left(K_{\mathrm{o}}\right)$ vs. vertical consolidation stress are plotted on a linear scale. Work data can be used for interpreting in situ stress conditions. $K_{\mathrm{o}}$ data define how horizontal stress changes during uniaxial (no radial strain) loading.
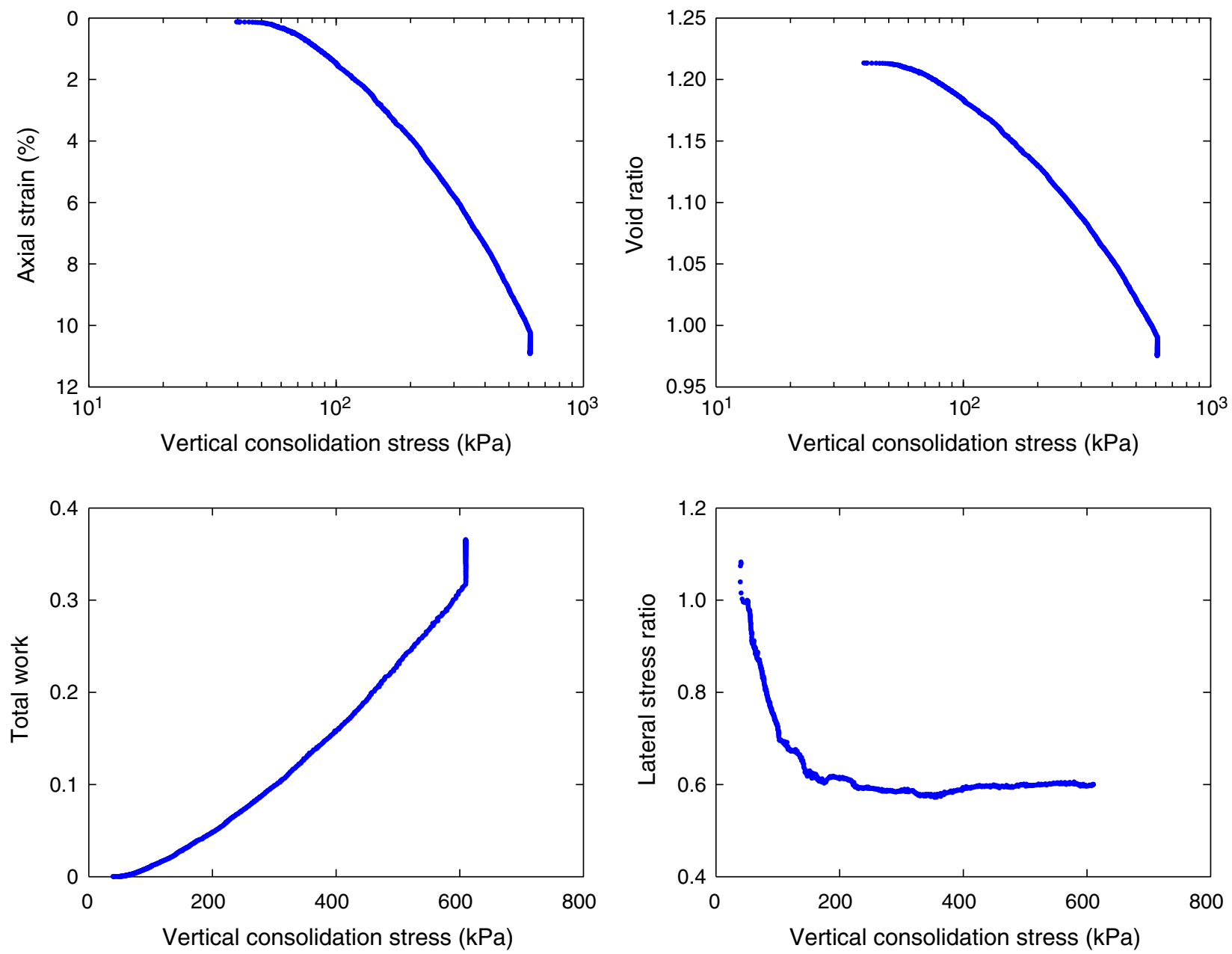
Figure F4. Example data from the shear phase of triaxial experiment TX729. Axial strain is during undrained shearing. $\mathrm{PP}=$ pore pressure.
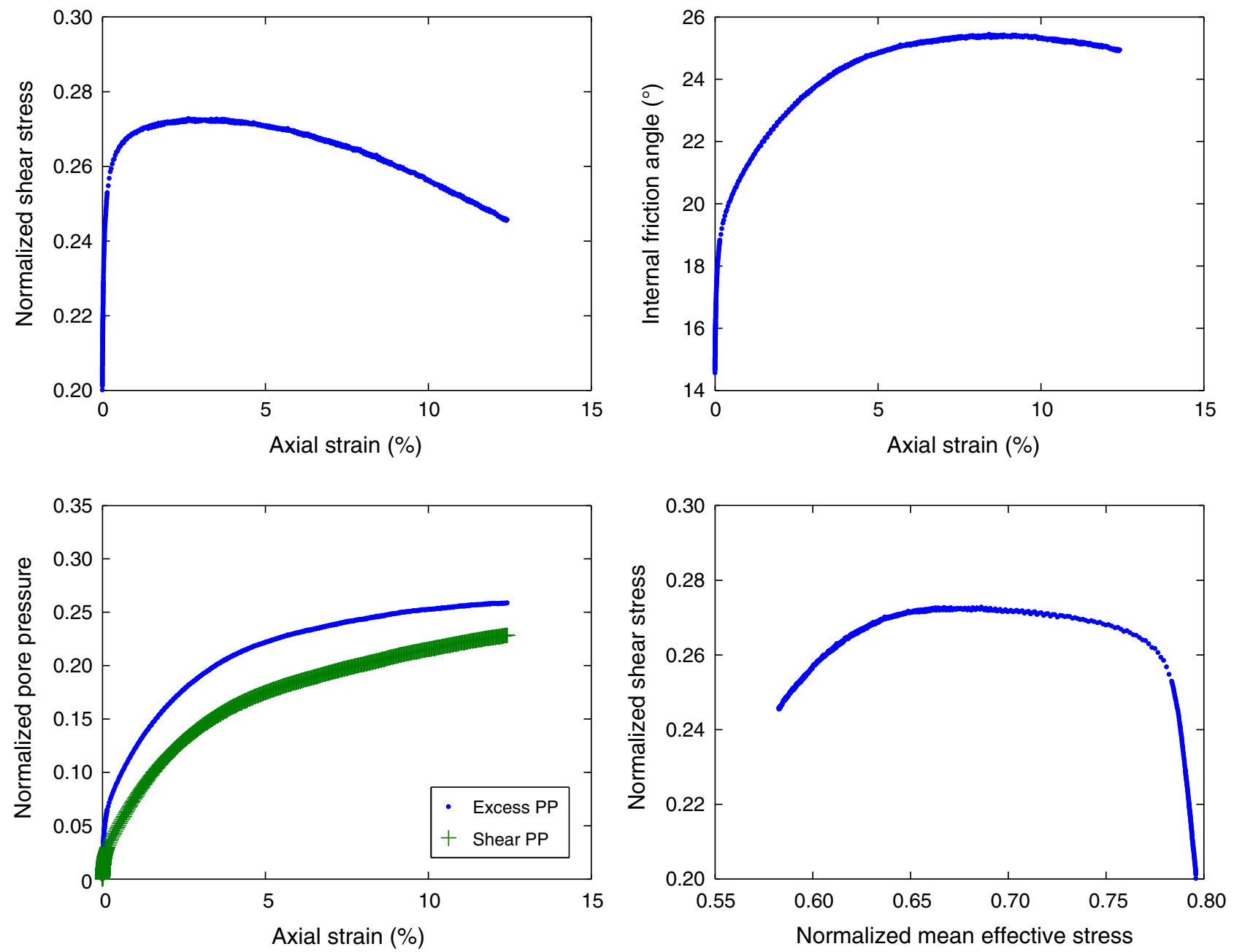
Table T1. Summary of samples used in triaxial experiments.

\begin{tabular}{lrll}
\hline \multicolumn{1}{c}{$\begin{array}{c}\text { Hole, core, } \\
\text { section }\end{array}$} & $\begin{array}{r}\text { Depth } \\
\text { (mbsf) }\end{array}$ & \multicolumn{1}{c}{ Test } & \multicolumn{1}{c}{ Comments } \\
\hline 308- & & & \\
U1322D-1H-2 & 42.9 & TX725 & \\
U1322D-2H-2 & 72.9 & TX728 & \\
U1322D-2H-2 & 72.7 & TX729 & \\
U1324B-10H-7 & 89.2 & TX730 & \\
U1324B-10H-7 & 88.9 & TX734 & \\
U1322B-4H-3 & 27.3 & TX735 & No void ratio data; included second shear \\
U1322D-2H-2 & 72.6 & TX736 & No void ratio data; included second shear \\
U1324B-10H-7 & 89.1 & TX737 & No void ratio data \\
U1324C-6H-3 & 304.0 & TX763 & \\
U1324B-18H-6 & 161.6 & TX764 & \\
U1322D-1H-2 & 42.6 & TX767 & \\
U1324C-6H-3 & 303.9 & TX770 & \\
U1322D-1H-2 & 42.7 & TX773 & \\
U1322D-1H-3 & 44.2 & TX774 & \\
U1322D-1H-3 & 44.1 & TX775 & \\
U1322D-1H-3 & 44.0 & TX776 & No consolidation data \\
U1322D-1H-3 & 43.9 & TX778 & No void ratio data \\
U1322D-1H-3 & 43.8 & TX779 & No void ratio data \\
\hline
\end{tabular}




\begin{tabular}{|c|c|c|c|c|c|c|c|c|c|c|c|c|c|c|c|c|c|c|c|c|c|c|c|c|}
\hline \multirow[b]{3}{*}{$\begin{array}{l}\text { Hole, core, } \\
\text { section }\end{array}$} & \multirow[b]{3}{*}{$\begin{array}{c}\text { Test } \\
\text { number }\end{array}$} & \multirow[b]{3}{*}{$\begin{array}{l}\text { Depth } \\
\text { (mbsf) }\end{array}$} & \multirow{2}{*}{\multicolumn{5}{|c|}{ Specimen data }} & \multirow{2}{*}{\multicolumn{5}{|c|}{ Test conditions }} & \multicolumn{12}{|c|}{ Consolidation results } \\
\hline & & & & & & & & & & & & & \multirow{2}{*}{ 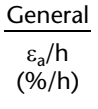 } & \multicolumn{5}{|c|}{ At maximum stress } & \multicolumn{6}{|c|}{ At preshear } \\
\hline & & & $\begin{array}{l}w_{n} \\
(\%)\end{array}$ & $\begin{array}{c}\rho_{\mathrm{t}} \\
\left(\mathrm{g} / \mathrm{cm}^{3}\right)\end{array}$ & $e_{\mathrm{i}}$ & $\begin{array}{c}S_{i} \\
(\%)\end{array}$ & $\mathrm{G}_{\mathrm{s}}$ & $\begin{array}{c}\sigma_{i}^{\prime} \\
(\mathrm{kPa})\end{array}$ & $\begin{array}{c}\varepsilon_{\mathrm{a}} \\
(\%)\end{array}$ & $\begin{array}{c}u_{\mathrm{b}} \\
(\mathrm{kPa})\end{array}$ & B & $\begin{array}{l}\varepsilon_{\mathrm{vol}} \\
(\%)\end{array}$ & & $\begin{array}{c}\varepsilon_{\mathrm{a}} \\
(\%)\end{array}$ & $\begin{array}{l}\varepsilon_{\mathrm{vol}} \\
(\%)\end{array}$ & $\begin{array}{l}\sigma_{\mathrm{vm}}^{\prime} \\
(\mathrm{kPa})\end{array}$ & $k_{c}$ & $\begin{array}{l}t_{\mathrm{s}} \\
(\mathrm{h})\end{array}$ & $\begin{array}{c}\varepsilon_{\mathrm{a}} \\
(\%)\end{array}$ & $\begin{array}{l}\varepsilon_{\mathrm{vol}} \\
(\%)\end{array}$ & $K_{c}$ & $\begin{array}{c}\sigma_{\mathrm{vc}}^{\prime} \\
(\mathrm{kPa})\end{array}$ & OCR & $\begin{array}{l}t_{\mathrm{s}} \\
(\mathrm{h})\end{array}$ \\
\hline \multicolumn{25}{|l|}{ 308- } \\
\hline U1322B-4H-3 & TX735 & 27.3 & 50.77 & 1.734 & 1.417 & 99.6 & 2.78 & 16.0 & 0.11 & 198 & 0.97 & -0.64 & 0.23 & 10.33 & 10.78 & 229.8 & 0.73 & 34.0 & 10.33 & 10.78 & 0.730 & 229.8 & 1 & 34.0 \\
\hline Second shear & TX735 & & & & & & & 67.7 & 9.67 & 284 & & 10.82 & 0.23 & 17.63 & 23.88 & 1164 & 0.989 & 45.0 & 17.63 & 23.88 & 0.989 & 1164 & 1 & 45.0 \\
\hline U1322D-1H-2 & TX767 & 42.7 & 43.59 & 1.765 & 1.262 & 96.0 & 2.78 & 27.5 & -0.21 & 296 & 0.86 & -2.06 & 0.11 & & 11.73 & 511 & 0.6 & 22.4 & & 11.73 & 0.600 & 511 & 1 & 22.4 \\
\hline U1322D-1H-2 & TX773 & 42.8 & 44.79 & 1.765 & 1.280 & 97.3 & 2.78 & 18.7 & -0.61 & 209 & & & 0.16 & 20.38 & 20.94 & 1433 & 0.7 & 30.9 & 20.80 & 20.94 & 0.7 & 1433 & 1 & 30.9 \\
\hline U1322D-1H-2 & TX725 & 42.9 & 44.00 & 1.780 & 1.249 & 98.0 & 2.78 & 46.0 & 0.06 & 294 & 0.90 & -0.90 & 0.13 & 14.59 & 14.31 & 963.4 & 0.663 & 38.7 & 14.59 & 14.31 & 0.663 & 963.4 & 1 & 38.7 \\
\hline U1322D-1H-3 & TX779 & 43.8 & & & & & & 32.4 & -0.39 & 206 & & & 0.24 & 21.45 & 21.59 & 1843 & 0.666 & 31.5 & 21.45 & 21.59 & 0.666 & 1843 & 1 & 31.5 \\
\hline U1322D-1H-3 & TX778 & 43.9 & & & & & & 33.2 & -0.11 & 285 & & & 0.21 & 6.45 & 6.38 & 285.9 & 0.56 & 19.5 & 6.45 & 6.38 & 0.560 & 285.9 & 1 & 19.5 \\
\hline U1322D-1H-3 & TX776 & 44.0 & & & & & & & & 214 & & & 0.2 & 21.00 & 21.10 & 1754 & 0.672 & & 21.00 & 21.10 & 0.672 & 1754 & 1 & \\
\hline U1322D-1H-3 & TX775 & 44.1 & 40.27 & 1.769 & 1.204 & 92.9 & 2.78 & 40.4 & -0.09 & 199 & & & 0.23 & 11.05 & 11.04 & 561.4 & 0.583 & 26.3 & 11.05 & 11.04 & 0.583 & 561.4 & 1 & 26.3 \\
\hline $1 \mathrm{H}-3$ & TX774 & 44.2 & 40.33 & 1.780 & 1.192 & 94.1 & 2.7 & 24.2 & -0.82 & 189 & & & 0 & 15.04 & 15.05 & 763.3 & 0.579 & 20.7 & 15.04 & 15.05 & 0.579 & 763.3 & 1 & 20.7 \\
\hline U1322D-2H-2 & TX736 & 72.6 & 40.77 & 1.826 & 1.143 & 99.2 & 2.78 & 17.0 & -0.26 & 197 & 0.94 & -1.83 & 0.2 & 6.08 & 6.19 & 252.1 & 0.558 & 34.7 & 6.08 & 6.19 & 0.558 & 252.1 & 1 & 34.7 \\
\hline Second shear & TX736 & & & & & & & 76.1 & 5.39 & 261 & 6.19 & & 0.16 & 14.64 & 15.45 & 1168 & 0.642 & 3.7 & 14.64 & 15.45 & 0.642 & 1168 & 1 & 3.7 \\
\hline U1322D-2H-2 & TX728 & 72.9 & 39.54 & 1.798 & 1.157 & 95 & 2 & 28.0 & 0.19 & 193 & 0.93 & -2 & & 11.38 & 11.33 & 703.8 & 0.648 & 54.0 & 11.38 & 11.33 & 0.648 & 703.8 & 1 & 54.0 \\
\hline U1322D-2H-2 & TX729 & 72.7 & 42.76 & 1.791 & 1.216 & 97.7 & 2. & 44.0 & -0.16 & 197 & 0.84 & -0.84 & 0.07 & 10.92 & 10.87 & 610 & 0.6 & 45.3 & 10.92 & 10.87 & 0.600 & 610.0 & 1 & 45.3 \\
\hline U1324B-10H-7 & TX737 & 89.1 & 38.90 & 1.796 & 1.149 & 94.1 & 2.78 & 50.0 & 0.06 & 178 & 0.84 & -0.73 & 0.21 & 14.08 & 14.36 & 1105 & 0.691 & 56.5 & 14.08 & 14.36 & 0.691 & 1105 & 1 & 56.5 \\
\hline U1324B-10H-7 & TX730 & 89.2 & 37.35 & 1.859 & 1.054 & 98.5 & 2.7 & 29.0 & 0.08 & 187 & 0.84 & & 0.07 & 9.94 & 9.88 & 586.8 & 0.638 & 43.0 & 9.94 & 9.88 & 0.638 & 586.8 & 1 & 43.0 \\
\hline U1324B-18H-6 & TX764 & 161.6 & 29.48 & 1.952 & 0.844 & 97.1 & 2.7 & 37.6 & -0.03 & 294 & 0.86 & -2.33 & 0.19 & 11.34 & 11.19 & 1461 & 0.494 & 66.9 & 11.34 & 11.19 & 0.494 & 1461 & 1 & 66.9 \\
\hline U1324C-6H-3 & TX770 & 303.9 & 28.34 & 1.944 & 0.835 & 94.3 & 2.78 & 32 & -0.54 & 295 & 0.88 & -5.56 & 0.17 & 8.67 & 8.56 & 1458 & 0.507 & 34.9 & 8.67 & 8.56 & 0.507 & 1458 & 1 & 34.9 \\
\hline U1324C-6H-3 & TX763 & 304.0 & 28.94 & 1.918 & 0.869 & 92.6 & 2.78 & 37.7 & -0.25 & 293 & 0.92 & -5.52 & 0.12 & 8.20 & 8.10 & 1418 & 0.509 & 31.9 & 8.20 & 8.10 & 0.509 & 1418 & 1 & 31.9 \\
\hline
\end{tabular}

Note: See Table T4 for heading definitions. 


\begin{tabular}{|c|c|c|c|c|c|c|c|c|c|c|c|c|c|c|c|c|c|c|c|c|c|c|c|c|c|c|c|}
\hline \multirow[b]{3}{*}{$\begin{array}{l}\text { Hole, core, } \\
\text { section }\end{array}$} & \multirow[b]{3}{*}{$\begin{array}{c}\text { Test } \\
\text { number }\end{array}$} & \multirow[b]{3}{*}{$\begin{array}{l}\text { Depth } \\
\text { (mbsf) }\end{array}$} & \multirow{2}{*}{\multicolumn{5}{|c|}{ Specimen Data }} & \multirow{2}{*}{\multicolumn{4}{|c|}{ Test conditions }} & \multicolumn{16}{|c|}{ Triaxial results } \\
\hline & & & & & & & & & & & & \multicolumn{8}{|c|}{ At maximum shear } & \multicolumn{8}{|c|}{ At maximum obliquity } \\
\hline & & & $\begin{array}{c}w_{\mathrm{n}} \\
(\%)\end{array}$ & $\begin{array}{c}\rho_{\mathrm{t}} \\
\left(\mathrm{g} / \mathrm{cm}^{3}\right)\end{array}$ & $e_{\mathrm{i}}$ & $\begin{array}{c}S_{i} \\
(\%)\end{array}$ & $\mathrm{G}_{\mathrm{s}}$ & $\begin{array}{l}\varepsilon_{a} / \mathrm{h} \\
(\% / \mathrm{h})\end{array}$ & $K_{\mathrm{c}}$ & $\begin{array}{c}\sigma_{\mathrm{vc}^{\prime}} \\
(\mathrm{kPa})\end{array}$ & OCR & $\begin{array}{l}\varepsilon_{\mathrm{a}} \\
(\%)\end{array}$ & $q / \sigma_{\mathrm{vc}}^{\prime}$ & $\begin{array}{l}\Delta u_{\mathrm{e}}{ }^{\prime} \\
\sigma_{\mathrm{vc}}{ }^{\prime}\end{array}$ & $\begin{array}{l}\Delta u_{\mathrm{s}} ! \\
\sigma_{\mathrm{vc}}{ }^{\prime}\end{array}$ & $p^{\prime} / \sigma_{\mathrm{vc}}{ }^{\prime}$ & $q / p^{\prime}$ & $\phi\left(^{\circ}\right)$ & $A$ & $\begin{array}{c}\varepsilon_{\mathrm{a}} \\
(\%)\end{array}$ & $q / \sigma_{\mathrm{vc}}{ }^{\prime}$ & $\begin{array}{l}\Delta u_{\mathrm{e}} l \\
\sigma_{\mathrm{vc}}{ }^{\prime}\end{array}$ & $\begin{array}{l}\Delta u_{\mathrm{s}}{ }^{\prime} \\
\sigma_{\mathrm{vc}} \mathrm{ve}^{\prime}\end{array}$ & $p^{\prime} / \sigma_{\mathrm{vc}}{ }^{\prime}$ & $q / p^{\prime}$ & $\phi\left(^{\circ}\right)$ & $A$ \\
\hline \multicolumn{28}{|l|}{$08-$} \\
\hline 3 & 735 & .3 & 50.77 & 1.734 & 1.417 & 99.6 & 2.78 & 66 & 0.730 & 29.8 & 1 & 5.00 & 0.279 & 0.336 & 0.238 & 0.673 & 0.415 & 24.5 & 1.160 & 4.98 & 0.279 & 0.336 & 0.238 & 0.673 & 0.415 & $5 \quad 24.5$ & 1.16 \\
\hline $\mathrm{Secc}$ & X735 & & & & & & & -0.58 & 0.989 & 1164 & 1 & -11.5 & -0.286 & 0.051 & 0.245 & $0.652-$ & $-0.438-$ & -26.0 & -0.090 & -11.5 & -0.286 & 0.051 & 0.245 & 0.652 & $2-0.438$ & $8-26$ & -0.09 \\
\hline $\mathrm{H}-2$ & х767 & 42.6 & 43.59 & 1.765 & 1.262 & 96.0 & . & -0.42 & 0.600 & 511 & 1 & -18.3 & -0.240 & -0.110 & 0.183 & 0.476 & $-0.505-$ & -30.4 & 0.125 & -16.94 & $4-0.239$ & -0.105 & 0.187 & 0.472 & $2-0.507$ & $7-30.5$ & 0.12 \\
\hline $\mathrm{H}-2$ & 773 & 42.7 & 44.79 & 1.765 & 1.28 & 97.3 & 2.78 & 0.48 & 0.700 & 143 & 1 & 3.15 & 0.241 & 0.231 & 0.170 & 0.713 & 0.339 & 19.8 & 1.260 & 8.57 & 0.232 & 0.296 & 0.241 & 0.638 & 0.363 & $3 \quad 21.3$ & 1.81 \\
\hline U132 & 725 & 42.9 & 44.00 & 1.780 & 1.249 & 98.0 & 2.78 & 0.53 & 0.663 & 963.4 & 1 & 2.35 & 0.213 & 0.159 & 0.117 & 0.712 & 0.298 & 17.4 & 1.260 & -8.97 & -0.163 & 0.003 & 0.239 & 0.465 & -0.352 & $2 \quad 20.6$ & -0.05 \\
\hline U13 & х779 & 43.8 & & & & & & 0.61 & 0.666 & 1843 & 1 & 3.11 & 0.237 & 0.170 & 0.124 & 0.726 & 0.326 & 19.0 & & 9.73 & 0.225 & 0.240 & 0.202 & 0.644 & 0.349 & $\begin{array}{ll}9 & 20.41\end{array}$ & $\begin{array}{ll}12.1 \\
1\end{array}$ \\
\hline $\mathrm{H}-3$ & 778 & 43.9 & & & & & & 48 & 0.560 & & 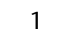 & 5.18 & 0.310 & 0.155 & 0.095 & 0.714 & 0.435 & 25.8 & & 7 & 0.376 & 0.166 & 0.108 & 0.700 & 0.537 & $\begin{array}{ll}7 & 32.5\end{array}$ & 0.95 \\
\hline $\mathrm{H}-3$ & 776 & 44.0 & & & & & & 0.51 & 0.672 & 1754 & 1 & 3.35 & 0.236 & 0.187 & 0.140 & 0.721 & 0.328 & 19.1 & 1.310 & 9.41 & 0.226 & 0.252 & 0.212 & 0.645 & 0.350 & $\begin{array}{ll}0 & 20.5\end{array}$ & 2.07 \\
\hline & & 44.1 & 40.27 & 1.769 & 1.204 & 92.9 & 2.7 & & 0.583 & & 1 & 3.34 & 0.280 & 0.157 & & & 0.397 & 23.4 & & 5.08 & 0.276 & 0.177 & & 0.681 & 0.405 & $\begin{array}{ll}5 & 23.9\end{array}$ & 1.29 \\
\hline & 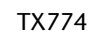 & 44.2 & 40.33 & 1.780 & 1.192 & 94.1 & 27 & & 0.5 & & 1 & 2.70 & 0.269 & 0.138 & 0.100 & 0. & 0.380 & 22.3 & 1. & 6.39 & 0.262 & 0.1 & & 0.654 & 0.400 & $\begin{array}{ll}0 & 23.6\end{array}$ & $5 \quad 1.81$ \\
\hline U132 & TX736 & 72.6 & 40.77 & 1.826 & 1.143 & 99.2 & 2.78 & 0.55 & 0.558 & 252.1 & 1 & 4.87 & 0.363 & 0.179 & 0.088 & 0.740 & 0.491 & 29.4 & 0.660 & -4.98 & -0.259 & -0.154 & 0.171 & 0.45 & -0.577 & $7-35.2$ & 0.158 \\
\hline & TX736 & & & & & & & 0.48 & 0.642 & 1168 & 1 & 3.94 & 0.242 & 0.264 & 0.220 & 0.613 & 0.395 & 23.3 & 2.0 & 7.41 & 0.237 & 0.295 & 0.255 & 0.577 & 0.411 & $\begin{array}{ll}1 & 24.3\end{array}$ & 2.49 \\
\hline & & & 42.76 & 91 & 16 & 97.7 & 2.78 & & 0.600 & & 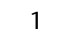 & 2.65 & 0.273 & 0.182 & 0.134 & 0.686 & 0.397 & 23.4 & 1.2 & 8.41 & 0.263 & 0.2 & 0 & 0.612 & 0.430 & $\begin{array}{ll}0 & 25.4\end{array}$ & 1.96 \\
\hline U132 & TX728 & 72.9 & 39.54 & 1.798 & 1.157 & 95.0 & 2.7 & 3 & 0.648 & 703.8 & 1 & 3.08 & 0.255 & 0.216 & 0.169 & 0.676 & 0.377 & 22.2 & 1.5 & 8.31 & 0.241 & 0.287 & 0.249 & 0.591 & 0.408 & $\begin{array}{ll}8 & 24.1\end{array}$ & 2.5 \\
\hline $\mathrm{H}-7$ & TX737 & 89.1 & 38.90 & 1.796 & 1.149 & 94.1 & 2.78 & 0.52 & 0.691 & 1105 & 1 & 4.79 & 0.258 & 0.262 & 0.201 & 0.679 & 0.380 & 22.3 & 1.300 & 10.34 & 0.249 & 0.32 & 0.257 & 0.62 & 0.402 & $2 \quad 23.7$ & 1.69 \\
\hline & 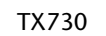 & & 37.35 & 1.859 & 1.054 & 98.5 & - & & 0.638 & & 4 & 7.23 & 0.291 & 0.2 & 0.1 & 0.673 & 0.432 & 25.6 & & 9.86 & 0.289 & 0.261 & & 0.664 & 0.435 & $\begin{array}{ll}5 & 25.8\end{array}$ & \\
\hline $8 \mathrm{H}-6$ & TX764 & 161.6 & 29.48 & 1.952 & 0.844 & 97.1 & 2.7 & -0.53 & 0.494 & 1461 & 1 & -12.4 & -0.181 & -0.011 & 0.278 & 0.323 & $-0.561-$ & -34.1 & 0.013 & -12 & -0.181 & -0.008 & 0.280 & 0.321 & -0.562 & $2-34.2$ & 0.01 \\
\hline-3 & TX770 & 303.9 & 28.34 & 1.944 & 0.835 & 94.3 & 2.78 & 0.35 & 0.507 & 1458 & 1 & 2.80 & 0.310 & 0.120 & 0.078 & 0.701 & 0.443 & 26.3 & 0.954 & 5.37 & 0.308 & 0.132 & 0.091 & 0.687 & 0.448 & $\begin{array}{ll}8 & 26.6\end{array}$ & 1.08 \\
\hline U1324C-6H-3 & TX763 & 304.0 & 28.94 & 1.918 & 0.869 & 92.6 & 2.78 & -0.28 & 0.509 & 1418 & 1 & -6.35 & -0.168 & -0.019 & 0.254 & 0.364 & $-0.461-$ & -27.4 & 0.020 & -6.7 & -0.166 & -0.009 & 0.264 & 0.354 & $4-0.469$ & $9-28.0$ & 0.01 \\
\hline
\end{tabular}

Notes: Negative values in TX735, TX767, TX736, TX764, and TX763 represent extensional triaxial tests; all other tests were compressional tests. See Table T4 for heading definitions. 
Table T4. Nomenclature.

\begin{tabular}{|c|c|c|c|}
\hline Variable & Definition & Dimension & SI unit \\
\hline$A$ & Pore pressure parameter & Dimensionless & - \\
\hline$B$ & $B$ value & Dimensionless & - \\
\hline$E$ & Secant modulus & $\mathrm{M} / \mathrm{LT}^{2}$ & $\mathrm{kPa}$ \\
\hline $\mathrm{G}_{\mathrm{s}}$ & Specific gravity of solid grains & Dimensionless & - \\
\hline$e_{\mathrm{i}}$ & Initial void ratio & Dimensionless & - \\
\hline$K_{\mathrm{c}}$ & Consolidation lateral stress ratio & Dimensionless & - \\
\hline$K_{\mathrm{o}}$ & In situ lateral stress ratio & Dimensionless & - \\
\hline OCR & Overconsolidation ratio & Dimensionless & - \\
\hline$p^{\prime}$ & Mean effective stress & $\mathrm{M} / \mathrm{LT}^{2}$ & $\mathrm{kPa}$ \\
\hline$q$ & Shear stress & $\mathrm{M} / \mathrm{LT}^{2}$ & $\mathrm{kPa}$ \\
\hline$S_{i}$ & Initial saturation & Dimensionless & $\%$ \\
\hline$t_{\mathrm{s}}$ & Time for secondary compression & $\mathrm{T}$ & $\mathrm{h}$ \\
\hline$u_{\mathrm{b}}$ & Backpressure & $\mathrm{M} / \mathrm{LT}^{2}$ & $\mathrm{kPa}$ \\
\hline$w_{\mathrm{n}}$ & Specimen water content & Dimensionless & $\%$ \\
\hline$u_{\mathrm{e}}$ & Excess pore pressure & $\mathrm{M} / \mathrm{LT}^{2}$ & $\mathrm{kPa}$ \\
\hline$u_{\mathrm{s}}$ & Shear induced pore pressure & $\mathrm{M} / \mathrm{LT}^{2}$ & $\mathrm{kPa}$ \\
\hline$\varepsilon_{\mathrm{a}} / \mathrm{h}$ & Strain rate & $1 / \mathrm{T}$ & $\% / h$ \\
\hline$\varepsilon_{\mathrm{a}}$ & Axial strain & Dimensionless & - \\
\hline$\varepsilon_{\mathrm{vol}}$ & Volumetric strain & Dimensionless & - \\
\hline$\rho_{\mathrm{t}}$ & Total density & $M / L^{3}$ & $\mathrm{~g} / \mathrm{cm}^{3}$ \\
\hline$\phi$ & Friction angle & Degrees & degrees \\
\hline$\sigma_{a}^{\prime}$ & Vertical effective stress & $\mathrm{M} / \mathrm{LT}^{2}$ & $\mathrm{kPa}$ \\
\hline$\sigma_{i}^{\prime}$ & Initial effective stress & $\mathrm{M} / \mathrm{LT}^{2}$ & $\mathrm{kPa}$ \\
\hline$\sigma_{\mathrm{r}}^{\prime}$ & Radial effective stress & $\mathrm{M} / \mathrm{LT}^{2}$ & $\mathrm{kPa}$ \\
\hline$\Delta \sigma_{\mathrm{r}}$ & Radial stress change & $\mathrm{M} / \mathrm{LT}^{2}$ & $\mathrm{kPa}$ \\
\hline$\Delta u$ & Pore pressure change & $\mathrm{M} / \mathrm{LT}^{2}$ & $\mathrm{kPa}$ \\
\hline$\sigma_{\mathrm{vm}}^{\prime}$ & Maximum vertical consolidation stress & $\mathrm{M} / \mathrm{LT}^{2}$ & $\mathrm{kPa}$ \\
\hline$\sigma_{\mathrm{vc}}^{\prime}$ & Vertical consolidation stress & $\mathrm{M} / \mathrm{LT}^{2}$ & $\mathrm{kPa}$ \\
\hline
\end{tabular}

Table T5. Example data from consolidation phase of triaxial experiment TX729. (See table notes.)

\begin{tabular}{rrrrrrrrrrrr}
\hline Time $(\mathrm{s})$ & $\varepsilon_{\mathrm{a}}(\%)$ & $\sigma_{\mathrm{a}}{ }^{\prime}(\mathrm{kPa})$ & $\sigma_{\mathrm{r}}{ }^{\prime}(\mathrm{kPa})$ & $p^{\prime}(\mathrm{kPa})$ & $q(\mathrm{kPa})$ & $\varepsilon_{\mathrm{vol}}(\%)$ & $e$ & $K_{\mathrm{o}}$ & Work & Area $\left(\mathrm{cm}^{2}\right)$ & $u_{\mathrm{b}}(\mathrm{kPa})$ \\
\hline 0 & 0.129 & 40.608 & 43.967 & 42.287 & -1.679 & 0.129 & 1.213 & 1.083 & 0.000 & 9.931 & 197.322 \\
41 & 0.129 & 40.919 & 44.131 & 42.525 & -1.606 & 0.129 & 1.213 & 1.078 & 0.000 & 9.931 & 197.271 \\
221 & 0.129 & 40.744 & 44.004 & 42.374 & -1.630 & 0.129 & 1.213 & 1.080 & 0.000 & 9.931 & 197.233 \\
401 & 0.128 & 40.043 & 43.008 & 41.526 & -1.483 & 0.130 & 1.213 & 1.074 & 0.000 & 9.931 & 197.132 \\
581 & 0.128 & 39.704 & 41.267 & 40.486 & -0.782 & 0.129 & 1.213 & 1.039 & 0.000 & 9.931 & 197.195 \\
761 & 0.130 & 40.838 & 41.467 & 41.153 & -0.314 & 0.129 & 1.213 & 1.015 & 0.000 & 9.931 & 197.601 \\
941 & 0.133 & 42.755 & 42.843 & 42.799 & -0.044 & 0.130 & 1.213 & 1.002 & 0.000 & 9.931 & 197.297 \\
1121 & 0.136 & 44.468 & 44.279 & 44.374 & 0.094 & 0.133 & 1.213 & 0.996 & 0.000 & 9.931 & 197.351 \\
1301 & 0.140 & 46.020 & 45.816 & 45.918 & 0.102 & 0.137 & 1.213 & 0.996 & 0.000 & 9.931 & 197.347 \\
1481 & 0.143 & 47.265 & 47.012 & 47.138 & 0.126 & 0.140 & 1.213 & 0.995 & 0.000 & 9.931 & 197.360 \\
1661 & 0.148 & 48.396 & 48.144 & 48.270 & 0.126 & 0.145 & 1.213 & 0.995 & 0.000 & 9.931 & 197.385 \\
1841 & 0.153 & 49.603 & 49.378 & 49.490 & 0.113 & 0.150 & 1.213 & 0.995 & 0.000 & 9.931 & 197.347 \\
2021 & 0.157 & 50.396 & 50.320 & 50.358 & 0.038 & 0.155 & 1.213 & 0.998 & 0.000 & 9.931 & 197.347 \\
2201 & 0.161 & 50.767 & 50.734 & 50.751 & 0.017 & 0.159 & 1.213 & 0.999 & 0.000 & 9.931 & 197.389 \\
2381 & 0.166 & 51.182 & 51.085 & 51.133 & 0.049 & 0.163 & 1.213 & 0.998 & 0.000 & 9.931 & 197.322 \\
2561 & 0.171 & 51.846 & 51.750 & 51.798 & 0.048 & 0.168 & 1.212 & 0.998 & 0.000 & 9.931 & 197.347 \\
2741 & 0.174 & 52.018 & 51.898 & 51.958 & 0.060 & 0.173 & 1.212 & 0.998 & 0.000 & 9.931 & 197.398 \\
2921 & 0.178 & 52.148 & 51.833 & 51.991 & 0.158 & 0.177 & 1.212 & 0.994 & 0.000 & 9.931 & 197.335 \\
3101 & 0.182 & 52.360 & 51.768 & 52.064 & 0.296 & 0.180 & 1.212 & 0.989 & 0.000 & 9.931 & 197.326 \\
3281 & 0.185 & 52.557 & 51.753 & 52.155 & 0.402 & 0.184 & 1.212 & 0.985 & 0.000 & 9.931 & 197.360 \\
3461 & 0.190 & 52.865 & 51.889 & 52.377 & 0.488 & 0.188 & 1.212 & 0.982 & 0.000 & 9.931 & 197.309 \\
3641 & 0.194 & 53.331 & 52.177 & 52.754 & 0.577 & 0.192 & 1.212 & 0.978 & 0.000 & 9.931 & 197.402 \\
\hline
\end{tabular}

Notes: Complete data available in the CONSOL folder in "Supplementary material." See Table T4 for heading definitions. 
Table T6. Example data from shear phase of triaxial experiment TX729. (See table notes.)

\begin{tabular}{ccccccccccc}
\hline Time $(\mathrm{s})$ & $\varepsilon_{\mathrm{a}}(\%)$ & $q / \sigma_{\mathrm{vc}}{ }^{\prime}$ & $p^{\prime} / \sigma_{\mathrm{vc}}{ }^{\prime}$ & $\Delta u_{\mathrm{e}} / \sigma_{\mathrm{vc}}{ }^{\prime}$ & $\Delta u_{\mathrm{s}} / \sigma_{\mathrm{vc}}{ }^{\prime}$ & $\Delta q / q_{\max }$ & $E / \sigma_{\mathrm{vc}}{ }^{\prime}$ & $A$ & $\phi\left(^{\circ}\right)$ & $\operatorname{Area}_{\left(\mathrm{cm}^{2}\right)}$ \\
\hline 0 & 0.000 & 0.200 & 0.796 & 0.000 & 0.000 & 0.000 & 0.000 & 0.000 & 14.564 & 9.938 \\
26 & 0.001 & 0.201 & 0.796 & 0.001 & 0.000 & 0.014 & 392.329 & 0.506 & 14.641 & 9.938 \\
28 & 0.001 & 0.201 & 0.796 & 0.001 & 0.000 & 0.018 & 328.457 & 0.524 & 14.661 & 9.938 \\
30 & 0.001 & 0.202 & 0.796 & 0.001 & 0.001 & 0.021 & 346.194 & 0.523 & 14.678 & 9.938 \\
32 & 0.001 & 0.202 & 0.796 & 0.002 & 0.001 & 0.024 & 361.002 & 0.522 & 14.694 & 9.938 \\
34 & 0.001 & 0.202 & 0.796 & 0.002 & 0.001 & 0.026 & 398.847 & 0.522 & 14.708 & 9.938 \\
36 & 0.001 & 0.202 & 0.796 & 0.002 & 0.001 & 0.029 & 305.878 & 0.536 & 14.726 & 9.938 \\
38 & 0.002 & 0.203 & 0.796 & 0.002 & 0.001 & 0.034 & 293.969 & 0.534 & 14.748 & 9.938 \\
40 & 0.002 & 0.203 & 0.796 & 0.003 & 0.001 & 0.037 & 292.411 & 0.536 & 14.767 & 9.938 \\
42 & 0.002 & 0.203 & 0.796 & 0.003 & 0.001 & 0.040 & 288.996 & 0.538 & 14.784 & 9.938 \\
44 & 0.003 & 0.203 & 0.796 & 0.003 & 0.001 & 0.042 & 227.688 & 0.544 & 14.798 & 9.938 \\
46 & 0.002 & 0.203 & 0.796 & 0.003 & 0.001 & 0.046 & 272.000 & 0.545 & 14.817 & 9.938 \\
48 & 0.002 & 0.204 & 0.796 & 0.004 & 0.002 & 0.049 & 342.499 & 0.551 & 14.837 & 9.938 \\
50 & 0.003 & 0.204 & 0.796 & 0.004 & 0.002 & 0.053 & 302.502 & 0.552 & 14.856 & 9.938 \\
52 & 0.003 & 0.204 & 0.796 & 0.004 & 0.002 & 0.056 & 289.963 & 0.555 & 14.873 & 9.938 \\
54 & 0.003 & 0.204 & 0.795 & 0.005 & 0.002 & 0.058 & 295.203 & 0.558 & 14.889 & 9.938 \\
56 & 0.003 & 0.205 & 0.795 & 0.005 & 0.002 & 0.062 & 285.947 & 0.556 & 14.907 & 9.938 \\
58 & 0.005 & 0.205 & 0.795 & 0.005 & 0.002 & 0.065 & 209.370 & 0.563 & 14.928 & 9.938 \\
60 & 0.004 & 0.205 & 0.795 & 0.005 & 0.002 & 0.069 & 260.126 & 0.563 & 14.947 & 9.938 \\
62 & 0.004 & 0.205 & 0.795 & 0.006 & 0.002 & 0.072 & 260.886 & 0.565 & 14.966 & 9.938 \\
64 & 0.004 & 0.206 & 0.795 & 0.006 & 0.003 & 0.074 & 275.935 & 0.569 & 14.981 & 9.938 \\
66 & 0.004 & 0.206 & 0.795 & 0.006 & 0.003 & 0.078 & 254.306 & 0.570 & 15.000 & 9.938 \\
\hline & & & & & & & & & &
\end{tabular}

Notes: Vertical consolidation stress $=610 \mathrm{kPa}$. Complete data available in the SHEAR folder in "Supplementary material." See Table T4 for heading definitions. 